\title{
Effect of thermal treatment on the catalytic activity of a Fe-rich bentonite for the photo-Fenton reaction
}

\section{(Efeito do tratamento térmico na atividade catalítica de uma bentonita rica em Fe para a reação foto-Fenton)}

\author{
B. M. Zimmermann ${ }^{1}$, S. Silvestri ${ }^{2}$, J. Leichtweis ${ }^{2}$, G. L. Dotto ${ }^{2}$, E.S. Mallmann ${ }^{2}$, E. L. Foletto ${ }^{2 *}$ \\ ${ }^{I}$ Federal University of Santa Maria, Department of Sanitary and Environmental Engineering, Santa Maria, RS, Brazil \\ ${ }^{2}$ Federal University of Santa Maria, Department of Chemical Engineering, 97105-900, Santa Maria, RS, Brazil
}

\begin{abstract}
The objective of this work was to evaluate the degradation of rhodamine B dye from aqueous solution by photo-Fenton reaction under visible irradiation using a Fe-rich bentonite as a catalyst. The material was thermally treated at a low temperature $\left(200{ }^{\circ} \mathrm{C}\right)$ and characterized by XRD, $\mathrm{N}_{2}$ adsorption-desorption isotherms, FTIR, SEM-EDS and XRF. Iron leaching in aqueous solution after the photo-Fenton reaction was evaluated by atomic absorption spectroscopy. The material exhibited a mesoporous structure, containing a specific surface area of $99 \mathrm{~m}^{2} . \mathrm{g}^{-1}$. The catalytic results showed significant dye degradation, reaching $95 \%$ of decolorization and $72 \%$ of mineralization at $300 \mathrm{~min}$ of reaction. The catalyst showed high chemical stability in four reaction cycles. Therefore, this thermally treated Fe-rich bentonite can be considered as a promising catalyst in the heterogeneous photo-Fenton reaction for the degradation of rhodamine B from aqueous solution.
\end{abstract}

Keywords: Fe-rich bentonite, characterization, photo-Fenton, rhodamine B, visible light.

\section{Resumo}

O objetivo deste trabalho foi avaliar a degradação do corante rodamina B em solução aquosa por reação foto-Fenton sob irradiação visivel utilizando uma bentonita rica em ferro como catalisador. O material foi tratado termicamente a baixa temperatura $\left(200{ }^{\circ} \mathrm{C}\right)$ e caracterizado por DRX, isotermas de adsorção-dessorção de $N_{2}, F T I R, M E V$-EDS e FRX. A lixiviação do ferro na solução aquosa após a reação foto-Fenton foi avaliada por espectroscopia de absorção atômica. O material exibiu uma estrutura mesoporosa, apresentando uma área de superfície específica de $99 \mathrm{~m}^{2} \cdot \mathrm{g}^{-1}$. Os resultados catalíticos mostraram alta eficiência na degradação do corante, atingindo $95 \%$ de descoloração e $72 \%$ de mineralização em 300 min de reação. O catalisador apresentou alta estabilidade química em quatro ciclos de reação. Portanto, esta bentonita rica em Fe tratada termicamente pode ser considerada como um promissor catalisador na reação foto-Fenton heterogênea para a degradação da rodamina $B$ em solução aquosa.

Palavras-chave: bentonita rica em Fe, caracterização, foto-Fenton, rodamina $B$, luz visível.

\section{INTRODUCTION}

The textile industries consume a large volume of water and, therefore, contribute to the generation of larger quantities of effluents containing dyes $[1,2]$. Dyes have a synthetic nature and a large number of aromatic rings on the molecular structure. These structures make them more chemically stable and thus more difficult to biodegrade [3]. Rhodamine B dye is widely used in the textile industry and as tracer material [4]. In addition, it is potentially harmful to humans, because can cause dermal, eye and respiratory tract irritation [5, 6]. This fact aggravates the problem of environmental impact and public health and makes the effluents treatment containing rhodamine B essential. In addition, when discharged into the environment, this dye may affect the aquatic life reducing light penetration. Adsorption

*efoletto@gmail.com

(D) https://orcid.org/0000-0003-2443-7445 process has been widely employed for the removal of rhodamine B dye in liquid effluents $[5,7,8]$. However, this technique only transfers the pollutant molecule from the aqueous phase to the solid phase [9]. Hence, there is a need to study alternative technologies, such as advanced oxidative processes (AOPs), which are considered highly effective in the degradation of organic molecules in aqueous solutions [10]. Among the AOPs, the Fenton process has been widely studied due to high efficiency in the degradation of different organic compounds from liquid effluents [11]. This is because the process is based on the generation of hydroxyl radicals $(\bullet \mathrm{OH})$, which are strongly oxidizing agents from the decomposition of hydrogen peroxide in the presence of iron ions at acidic conditions $[12,13]$. The use of irradiation on this process (known as photo-Fenton) increase the production of $\bullet \mathrm{OH}$ radicals [14], causing a higher degradation rate of organic molecules [15-17].

Bentonite is an aluminosilicate mineral clay containing a significant fraction of smectite-group phase [18-20]. It is 
ubiquitous in most soils, exhibits a low cost, low permeability and has excellent characteristics for the diffusion of pollutant molecules. Due to its high specific surface area and cation exchange capacity, it is widely applied as adsorbent and catalyst [21]. Several works addressing the impregnation of iron on bentonites for employing as a Fenton-catalyst have been published. Fe-supported bentonite or Fe-pillared bentonite has been widely used as catalysts in Fenton reaction [16, 22, 23]. In these cases, bentonite samples containing poor content of iron need to be modified. Herein, we use a Fe-rich raw bentonite as a photo-Fenton catalyst, not requiring any impregnation with iron. These clays can have their physical characteristics modified when thermally treated [24-26]. According to [25], the thermal treatment at a low temperature (up to $300{ }^{\circ} \mathrm{C}$ ) can lead to a substantial increase in terms of surface area and pore volume. Therefore, the thermal treatment of the bentonite at a low temperature can be sufficient to increase the reactivity of its surface and facilitate the diffusion of molecules in the material structure [27]. In this work, an iron-rich raw bentonite was thermally treated at low temperature $\left(200{ }^{\circ} \mathrm{C}\right)$ and subsequently applied as a catalyst for the degradation of rhodamine $\mathrm{B}$ $(\mathrm{RhB})$ through the heterogeneous photo-Fenton process under visible irradiation.

\section{EXPERIMENTAL}

Chemicals and materials: rhodamine B (Synth), $\mathrm{H}_{2} \mathrm{O}_{2}$ (30\%, Sigma-Aldrich), $\mathrm{H}_{2} \mathrm{SO}_{4}$ (Proquimios), and $\mathrm{NaOH}_{2}^{2}$ (Dinâmica) were used without further purification. In this work, an iron-rich raw bentonite sample from Lages city (Santa Catarina State, Brazil) was exposed at $200{ }^{\circ} \mathrm{C}$ in a drying oven for $24 \mathrm{~h}$. This bentonite sample has also been employed in other previous studies as an adsorbent in its raw form [28] and as an adsorbent modified by acid-activation assisted by microwave [29].

Characterization techniques: X-ray diffraction (XRD) analysis using a Rigaku-Miniflex 300 diffractometer, operated with $\mathrm{CuK} \alpha(\lambda=1.54051 \AA), 30 \mathrm{kV}, 10 \mathrm{~mA}$, step size $0.03^{\circ}$, acquisition time of $0.9 \mathrm{~s}$ by step and scan range of $2 \theta=$ 5 to $45^{\circ}$. $\mathrm{N}_{2}$ adsorption-desorption isotherms were obtained by using the Micromeritics ASAP 2020 equipment at 77 $\mathrm{K}$. Total pore volume and average pore size analysis was obtained by the BJH (Barret, Joyner and Halenda) method, while the specific surface area analysis was obtained by the BET (Brunauer, Emmett and Teller) method. Fouriertransform infrared (FTIR) spectroscopy was performed by the Shimadzu-IR Prestige 21 equipment. Scanning electron microscopy (SEM, Jeol, JSM 6010LV) coupled with an energy dispersive X-ray spectroscopy (EDS) microprobe was employed to determine the morphology and chemical composition of the powders. The chemical composition of the powders was also determined by X-ray fluorescence (XRF) spectrometry (Bruker, S8 Tiger).

Degradation essays by photo-Fenton reaction: the photo-Fenton experiments were performed in a batchtype glass reactor $(200 \mathrm{~mL})$. The experimental conditions were: $\mathrm{RhB}$ concentration of $50 \mathrm{mg} \cdot \mathrm{L}^{-1}$, hydrogen peroxide concentration of $5.8 \mathrm{mmol} . \mathrm{L}^{-1}$, catalyst amount of $0.1 \mathrm{~g}, \mathrm{pH}$ 2.9 , solution volume of $100 \mathrm{~mL}$, and $25^{\circ} \mathrm{C}$. Before reaction, the solution was stirred in dark for $120 \mathrm{~min}$ to achieve adsorption equilibrium. The reaction was initiated when the visible light (commercial fluorescent lamp 85W, Empalux) was turned on, and subsequently $\mathrm{H}_{2} \mathrm{O}_{2}$ was added into the $\mathrm{RhB}$ solution. At predetermined time intervals, $5 \mathrm{~mL}$ of the dye solution was removed and centrifuged for further color reading at a wavelength of $554 \mathrm{~nm}[30,31]$ on the UVvisible spectrophotometer (SP1105, BEL Photonics). These aliquots were also subjected to analysis of total organic carbon (TOC) on a TOC-L CPH/CPN analyzer (Shimadzu) in order to determine the mineralization degree. Carbon mineralization consists in the conversion of carbonaceous compounds to carbon dioxide. The decolorization efficiency (DE) was determined by:

$$
\operatorname{DE}(\%)=\left(1-\frac{\mathrm{C}}{\mathrm{C}_{0}}\right) \cdot 100
$$

where $\mathrm{C}_{0}$ is the initial concentration of dye and $\mathrm{C}$ is the concentration at a given reaction time. The mineralization efficiency (ME) was calculated by:

$$
\mathrm{ME}(\%)=\ln \left(\frac{\mathrm{TOC}}{\mathrm{TOC}_{0}}\right) \cdot 100
$$

where TOC is the initial total organic carbon concentration and $\mathrm{TOC}_{0}$ is the concentration at reaction time t. For comparison purposes, a raw bentonite sample (no thermal treated) was also used in the catalytic tests. The iron leaching in the reaction medium was evaluated at $300 \mathrm{~min}$ of reaction time using an atomic absorption spectrophotometer (Agilent Technol., 240 FSAA).

Intermediate products analysis: the possible intermediate products formed during the $\mathrm{RhB}$ degradation were evaluated using the liquid chromatography coupled to mass spectrometry (LC-MS) technique using an electrospray ionization mass spectrometer (ESI-MS, Agilent Technol., 6460 Triple Quadrupole LC/MS). Aliquots were collected at 60 and $300 \mathrm{~min}$ of reaction, filtered using a syringe filter (PVDF membrane with $0.45 \mu \mathrm{m}$ pore size) and then adjusted $\mathrm{pH}$ using $\mathrm{NaOH}$ solution (3M) in order to interrupt the reaction. In the equipment, nitrogen was used as nebulization and collision gas at $300^{\circ} \mathrm{C}$ and flow of $5 \mathrm{~L} \cdot \mathrm{min}^{-1}$. The nebulizer remained at a pressure of 45 psi. The capillary voltage was $3500 \mathrm{~V}$ and that of the fragmentator was $3 \mathrm{kV}$. Samples were introduced at a flow rate of $0.8 \mathrm{~mL} \cdot \mathrm{min}^{-1}$. The introduction procedure of the samples was direct insertion, without the presence of a chromatographic column. The fragments of the selected precursor ions were analyzed by the ionic method, with collision energy of $0,5,10$ and $15 \mathrm{eV}$ in order to better elucidate all the molecules.

\section{RESULTS AND DISCUSSION}

Fig. 1 shows the X-ray diffraction patterns of raw and thermally treated samples. The major characteristic peak of 
the smectite was detected at $2 \theta=5.6^{\circ}$, which was attributed to the reflection plane (001). No significant change was detected on the position of the 001 peak and the interplanar distance $\mathrm{d}_{(001)}$ value (about $1.537 \mathrm{~nm}$ ) for the thermally treated sample when compared to its raw form. In addition, the presence of quartz was also identified at $2 \theta=26^{\circ}[28,32]$.

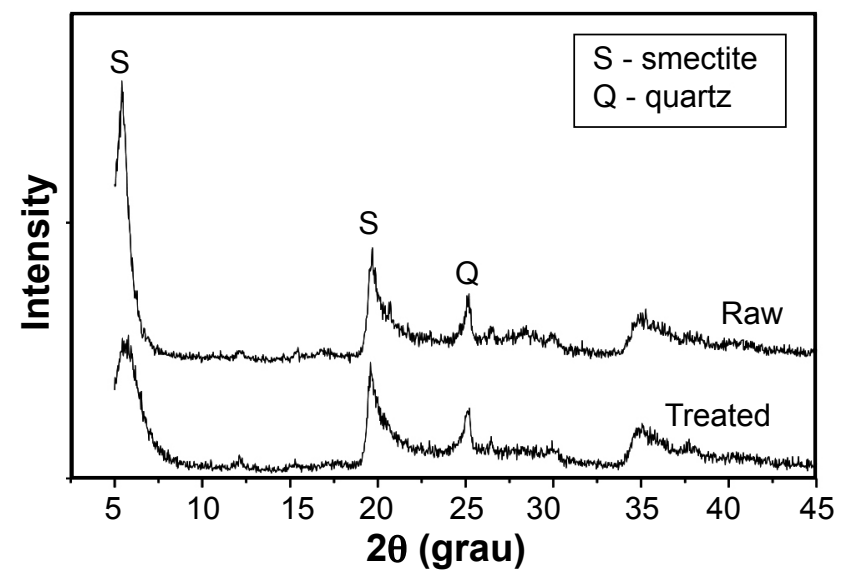

Figure 1: XRD patterns of raw and thermally treated samples.

[Figura 1: Difratogramas de raios $X$ das amostras natural $e$ tratada termicamente.]

The nitrogen adsorption-desorption isotherms for the raw and thermally treated samples are shown in Fig. 2. According to IUPAC classification, the isotherm for the thermally treated sample was type IV, representing a predominantly mesoporous structure, while the isotherm for the raw sample was classified as type III, indicating predominantly microporous particles [33]. The pore characteristics of the powders were obtained from the BET and BJH methods. The thermally treated bentonite presented a surface area of $99 \mathrm{~m}^{2} \cdot \mathrm{g}^{-1}$, while the same clay sample in its raw form presented $14.35 \mathrm{~m}^{2} \cdot \mathrm{g}^{-1}$. Therefore, the thermal treatment at $200{ }^{\circ} \mathrm{C}$ significantly increased the surface area of the sample, about seven times. In addition, a significant increase in the total pore volume occurred after the thermal treatment $\left(0.142 \mathrm{~cm}^{3} \cdot \mathrm{g}^{-1}\right)$ compared to the same sample in its raw form $\left(0.0873 \mathrm{~cm}^{3} \cdot \mathrm{g}^{-1}\right)$. Bayram et al. [25] found specific surface area and pore volume values of $44 \mathrm{~m}^{2} \cdot \mathrm{g}^{-1}$ and $0.100 \mathrm{~cm}^{3} \cdot \mathrm{g}^{-1}$ for a raw bentonite sample and $105 \mathrm{~m}^{2} \cdot \mathrm{g}^{-1}$ and $0.155 \mathrm{~cm}^{3} \cdot \mathrm{g}^{-1}$, respectively, after treatment at $300{ }^{\circ} \mathrm{C}$, remaining approximately constant as the temperature increased up to $700{ }^{\circ} \mathrm{C}$. This improvement on the physical properties can be attributed to the elimination of hydration water as well as some small structural disorganization when the bentonite is treated up to $300{ }^{\circ} \mathrm{C}[25,26]$, generating additional porosity on the particles. Thus, these improved physical characteristics generally promote higher yields on the photo-Fenton process, because the reaction occurs on the surface of the catalyst.

FTIR spectra of raw and thermally treated samples are shown in Fig. 3. No change was observed after the thermal treatment. The spectra exhibited absorption bands around 3450 and $1650 \mathrm{~cm}^{-1}$, which can be attributed to the stretching and bending vibrations of the $-\mathrm{OH}$ groups, respectively.

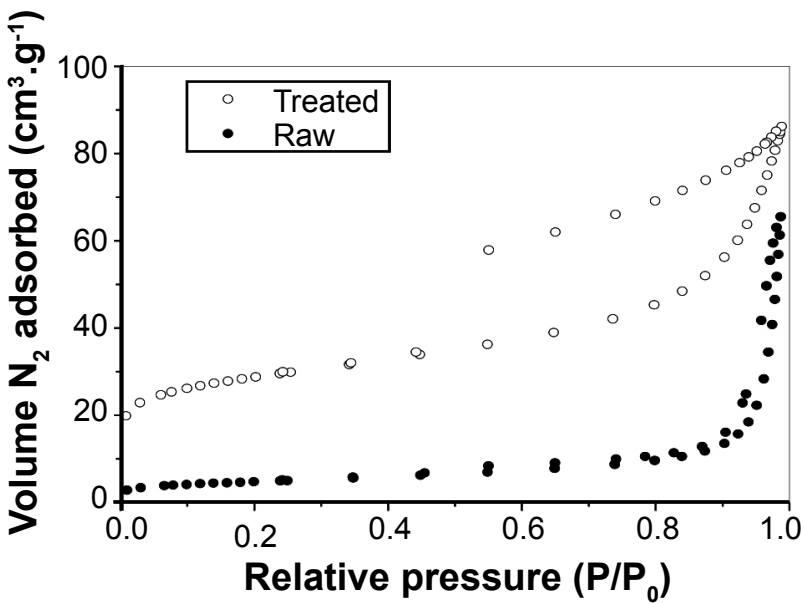

Figure 2: Nitrogen adsorption-desorption isotherms of raw and thermally treated samples.

[Figura 2: Isotermas de adsorção-dessorção de $N_{2}$ das amostras natural e tratada termicamente.]

These groups represent the water molecules adsorbed on the surface of the material $[34,35]$. The intense band at 1030 $\mathrm{cm}^{-1}$ was related to the stretching of the Si-O-Si bond in the tetrahedral sheet $[35,36]$. Bands at 795 and $520 \mathrm{~cm}^{-1}$ corresponded to the bending of Si-O (quartz) bonds and $\mathrm{Si}$ $\mathrm{O}-\mathrm{Al}$ bonds, respectively $[35,37]$. It was also possible to observe the Al-OH group at $915 \mathrm{~cm}^{-1}[38,39]$.

Fig. 4 shows the SEM image and elemental analysis (EDS) of treated bentonite sample. SEM image (Fig. 4a) revealed that the sample presented particles with irregular sizes and shapes. In addition, it was possible to observe particles with size below $50 \mu \mathrm{m}$. From EDS analysis (Fig. $4 \mathrm{~b}$ ), the major elements were $\mathrm{Si}, \mathrm{Al}$, and $\mathrm{Fe}$, being the iron content equivalent to $10.3 \mathrm{wt} \%$ in terms of $\mathrm{Fe}_{2} \mathrm{O}_{3}$. The chemical composition ( $\mathrm{wt} \%$ ) obtained from XRF analysis of treated sample was $55.56 \mathrm{SiO}_{2}, 25.05 \mathrm{Al}_{2} \mathrm{O}_{3}, 9.75 \mathrm{Fe}_{2} \mathrm{O}_{3}, 1.37$ $\mathrm{MgO}, 1.55 \mathrm{P}_{2} \mathrm{O}_{5}, 1.08 \mathrm{TiO}_{2}, 0.33 \mathrm{~K}_{2} \mathrm{O}, 0.11 \mathrm{Na}_{2} \mathrm{O}, 0.07 \mathrm{CaO}$, $0.02 \mathrm{MnO}$, and 5.11 loss on ignition (mass loss of the sample heated to $900{ }^{\circ} \mathrm{C}$ ). From the results of chemical analysis, it was possible to infer that the values of iron amount determined by both the techniques were close. Therefore,



Figure 3: FTIR spectra of raw and thermally treated samples.

[Figura 3: Espectros de FTIR das amostras natural e tratada termicamente.] 

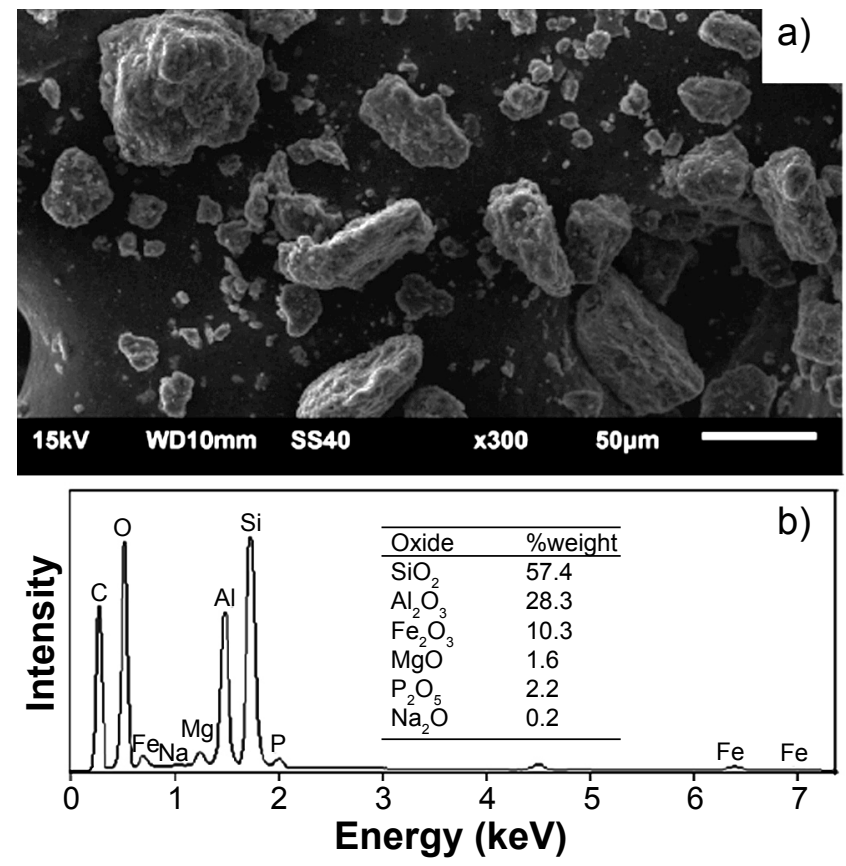

Figure 4: SEM image (a) and EDS spectrum (b) of thermally treated bentonite.

[Figura 4: Imagem de MEV (a) e espectro de EDS (b) da bentonita tratada termicamente.]

the high amount of iron in the bentonite demonstrated its applicability as a potential catalyst in photo-Fenton reaction to degrade organic pollutant molecules from liquid effluents.

Fig. 5 shows a comparison of the catalytic efficiencies for the raw and thermally treated samples under visible light. The thermally treated bentonite presented superior adsorption and decolorization efficiency compared to raw bentonite (Fig. 5a). The thermally treated bentonite presented $95 \%$ of $\mathrm{RhB}$ decolorization, while that the raw bentonite reached $65 \%$ at $300 \mathrm{~min}$. In addition, the thermally treated sample reached $72 \%$ of TOC removal, whereas the raw sample showed $35 \%$ of TOC removal at 300 min (Fig. 5b). Therefore, according to these results, the thermally treated

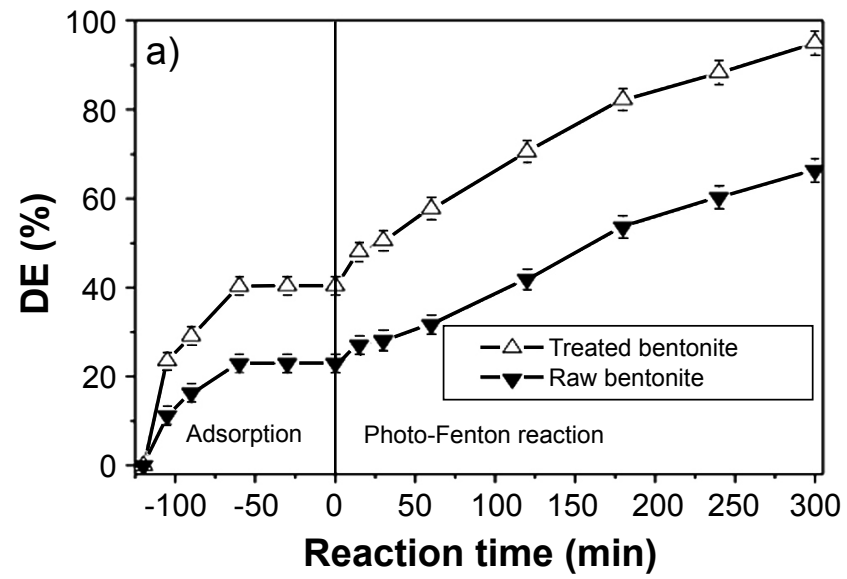

bentonite was chosen as a catalyst for the later studies of this work, such as the determination of the possible intermediate products formed during the $\mathrm{RhB}$ degradation as well as the Fe leaching analysis.

The possible intermediate products formed during the $\mathrm{RhB}$ degradation using the thermally treated bentonite as a catalyst were proposed by the $\mathrm{m} / \mathrm{z}$ (mass/charge number of ions) values and are presented in the mass spectrum in Fig. 6. According, the signal in $\mathrm{m} / \mathrm{z}=443$ corresponded to dye molecule. Throughout the reaction, the intensity of this signal reduced and new intermediates were formed, confirming the degradation of the dye molecule in the liquid solution. This fragmentation might have resulted in the formation of the intermediates represented by the mass peaks $\mathrm{m} / \mathrm{z}=$ $367,225,159$ and 90 . In $\mathrm{m} / \mathrm{z}=367$, the breakdown of the four double bonds $\mathrm{N}=\mathrm{CH}$ and breakdown of the carboxylic acid $-\mathrm{OH}$ bond were detected. Mass peak 225 showed the breakdown of the double bond on the benzene ring $(=\mathrm{N})$ and the loss of the $-\mathrm{COH}$ on the benzene ring that was attached to the central ring. The intermediate $\mathrm{m} / \mathrm{z}=159$ was assigned to cleavage of the extreme aromatic rings. Some fragments of the functional group $\cdot \mathrm{COOH}$ may have rearranged and formed new molecules such as $\mathrm{m} / \mathrm{z}=90$ (oxalic acid). This rearrangement hypothesis may justify the fact that some mass peaks did not have their fragments identified. Also, the peaks with mass 225 and 90 showed an increase in the intensity, which meant the existence of a greater fragments amount of these compounds in the solution. Therefore, partial degradation of the RhB dye occurred, showing that the reactions with the hydroxyl radical were not selective, but rather were driven by the reactivity of the groups present in the dye molecule.

The thermally treated bentonite was evaluated in several cycles of reuse for the decolorization of $\mathrm{RhB}$ dye (Fig. 7), following the same experimental conditions previously mentioned. This sample showed practically the same efficiency over the four recycles, showing high stability and catalytic activity. According to the Fe leaching analysis by atomic absorption spectrophotometry, a low iron amount

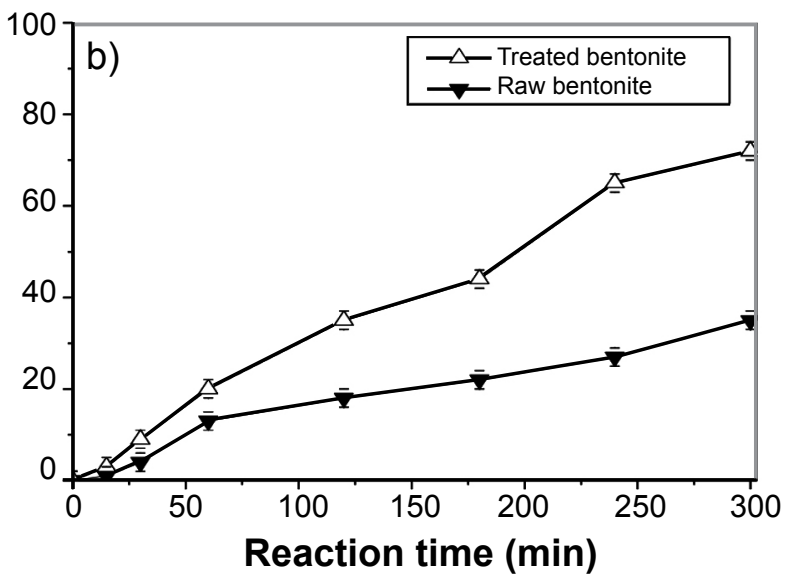

Figure 5: Comparison of catalytic activity between raw and thermally treated bentonite samples for RdB decolorization (a) and mineralization (b).

[Figura 5: Comparação da atividade catalítica entre as amostras de bentonita natural e tratada termicamente para descoloração (a) e mineralização (b) da rodamina $B$. 


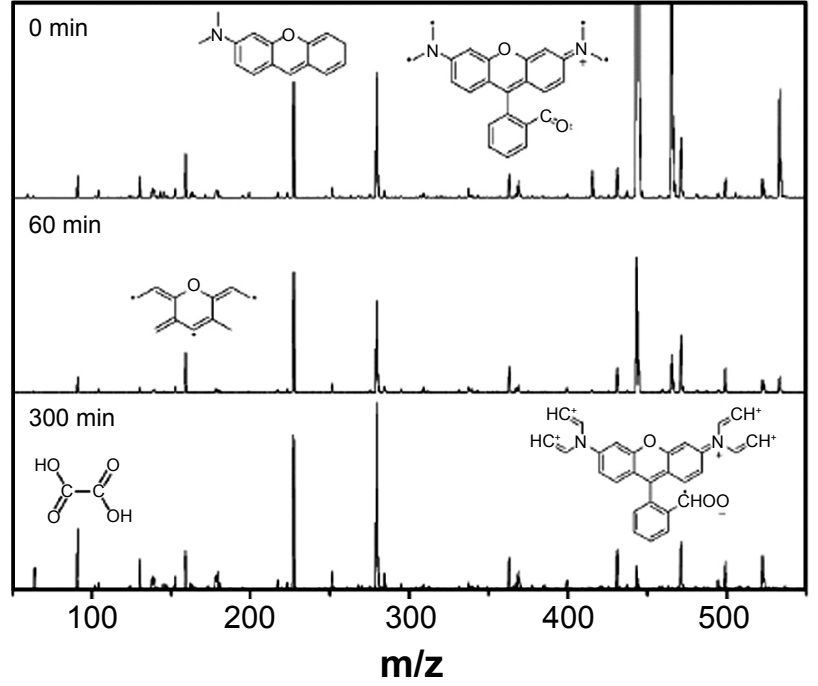

Figure 6: Proposed mass fragmentation of the $\mathrm{RhB}$ dye by the thermally treated bentonite.

[Figura 6: Proposta da fragmentação em massa do corante rodamina $B$ pela bentonita tratada termicamente.]

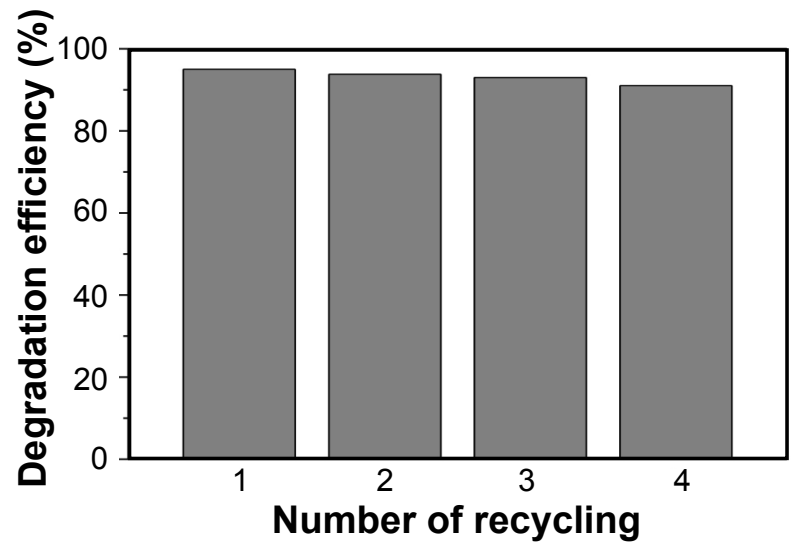

Figure 7: Reusability of catalyst.

[Figura 7: Reusabilidade do catalisador.]

was found in the solution after each photo-Fenton reaction using the thermally treated bentonite as catalyst (below $\left.1.71 \mathrm{mg} . \mathrm{L}^{-1}\right)$. This result indicated that the iron was present on the layer structure of the clay, which occurred from the natural isomorphic substitution of $\mathrm{Al}^{3+}$ with $\mathrm{Fe}^{2+}$ in the octahedral sites of smectite [25]. The Fe leaching value was far below the maximum limit allowed in Brazilian legislation, which is $15 \mathrm{mg} . \mathrm{L}^{-1}$ of iron for the wastewaters discharge in rivers [40]. Therefore, the thermally treated bentonite showed a high chemical stability in the photoFenton reaction for the degradation of rhodamine B dye in aqueous solution.

\section{CONCLUSIONS}

The thermally treated Fe-rich bentonite exhibited more favorable characteristics for the photo-Fenton process compared to raw bentonite. The particles of thermally treated Fe-rich bentonite presented a predominantly mesoporous structure and high specific surface area. These characteristics were essential to promote a satisfactory catalytic activity toward the rhodamine B degradation from aqueous solution. The thermally treated bentonite showed high efficiency, reaching $95 \%$ of $\mathrm{RhB}$ decolorization and $72 \%$ of mineralization at $300 \mathrm{~min}$. From the LC-MS analysis, it was possible to prove the cleavage of the $\mathrm{RhB}$ molecule through the photo-Fenton process. The thermally treated bentonite showed to be a catalyst with high chemical stability. Therefore, the thermally treated Fe-rich bentonite proved to be a potential photo-Fenton catalyst for the degradation of rhodamine $\mathrm{B}$ in aqueous solution.

\section{ACKNOWLEDGEMENTS}

The authors sincerely thank the Coordenação de Aperfeiçoamento de Pessoal de Nível Superior (CAPES PNPD grant \#20132633-42002010038P6) and Conselho Nacional de Desenvolvimento Científico e Tecnológico (CNPq) for the financial support.

\section{REFERENCES}

[1] Q. Chen, F. Ji, T. Liu, P. Yan, W. Guan, X. Xu, Chem. Eng. J. 229 (2013) 57.

[2] M. Rafatullah, O. Sulaiman, R. Hashim, A. Ahmad, J. Hazard. Mater. 177 (2010) 70.

[3] T.A. Nguyen, R.S. Juang, Chem. Eng. Sci. 219 (2013) 109.

[4] N. Barka, S. Qourzal, A. Assabbane, A. Nounah, Y. AitIchou, J. Photoch. Photobio. A 195 (2008) 346.

[5] Z. Cheng, Y. Li, Z. Liu, J. Ind. Eng. Chem. 55 (2017) 234.

[6] T.A. Khan, S. Dahiya, I. Ali, Appl. Clay Sci. 69 (2012) 58.

[7] S.H. da Silva Filho, P. Vinaches, B. Sibele, C. Pergher, Mat. Lett. 227 (2018) 258.

[8] S.H. Alwan, H.A.H. Alshamsi, L.S. Jasim, J. Mol. Struct. 1161 (2018) 356.

[9] M. Fayazi, M.A. Taher, D. Afzali, A. Mostafavi, J. Mol. Liq. 216 (2016) 781.

[10] Q. Wu, H. Zhang, L. Zhou, C. Bao, H. Zhu, Y. Zhang, J. Taiwan Inst. Chem. Eng. 67 (2016) 484.

[11] N. Wang, T. Zheng, G. Zhang, P. Wang, J. Environ. Chem. Eng. 4 (2016) 762.

[12] M.F. Hou, L. Liao, W.D. Zhang, X.Y. Tang, H.F. Wan, G.C. Yin, Chemosphere 83 (2011) 1279.

[13] M. Munoz, Z.M. Pedro, J.A. Casas, J.J. Rodriguez, Appl. Catal. B 176-177 (2015) 249.

[14] T. Xu, Y. Liu, F. Ge, Y. Ouyang, Appl. Clay Sci. 100 (2014) 35.

[15] C.G. Anchieta, A. Cancelier, M.A. Mazutti, S.L. Jahn, R.C. Kuhn, A. Gündel, O. Chiavone-Filho, E.L. Foletto, Materials 7 (2014) 6281.

[16] Y. Gao, Y. Wang, H. Zhang, Appl. Catal. B 178 (2015) 29.

[17] Z. Huang, P. Wu, B. Gong, S. Yang, H. Li, Z. Zhu, L. Cui, Appl. Surf. Sci. 370 (2016) 209. 
[18] E.L. Foletto, C. Volzone, L.M. Porto, Braz. J. Chem. Eng. 20 (2003) 139.

[19] E.L. Foletto, G.C. Colazzo, C. Volzone, L.M. Porto, Braz. J. Chem. Eng. 28 (2011) 169.

[20] Z. Vryzas, V.C. Kelessidis, L. Nalbantian, V. Zaspalis, D.I. Gerogiorgis, Y. Wubulikasimu, Appl. Clay Sci. 136 (2017) 26.

[21] P. Zong, X. Wu, J. Gou, X. Lei, D. Liu, H. Deng, J. Mol. Liq. 209 (2015) 358.

[22] L.F. González-Bahamón, D.F. Hoyos, N. Benítez, C. Pulgarín, Chemosphere 82 (2011) 1185.

[23] J. Chen, L. Zhu, J. Hazard. Mater. 185 (2011) 1477.

[24] L. Andrini, R.M. Toja, M.R. Gauna, M.S. Conconi, F.G. Requejo, N.M. Rendtorff, Appl. Clay Sci. 137 (2017) 233.

[25] H. Bayram, M. Önal, H. Yılmaz, Y. Sarıkaya, J. Therm. Anal. Calorim. 101 (2010) 873.

[26] G. Yilmaz, Sci. Res. Essays 6 (2011) 1928.

[27] B. Momani, Polymers 93 (2016) 204.

[28] B.M. Zimmermann, G.L. Dotto, R.C. Kuhn, M.A. Mazutti, H. Treichel, E.L. Foletto, Int. J. Environ. Technol. Manage. 19 (2016) 1.

[29] E.L. Foletto, D.S. Paz, A. Gündel, Appl. Clay Sci. 83-84 (2013) 63.
[30] K. Peng, L. Fu, H. Yang, J. Ouyang, Sci. Rep. 6 (2016) 1. [31] F. Persico, M. Sansotera, C.L. Bianchi, C. Cavallotti, W. Navarrini, Appl. Catal. B 170-171 (2015) 83.

[32] G.W. Brindley, G. Brown, Crystal structures of clay minerals and their X-ray identification, Ed. Mineral. Soc., London (1980) 495.

[33] M. Thommes, Pure Appl. Chem. 87 (2015) 1.

[34] A.M. Elfadly, I.F. Zeid, F.Z. Yehia, M.M. Abouelela, A.M. Rabie, Fuel Process. Technol. 163 (2017) 1.

[35] F.I. Khalili, M. Sultan, C. Robl, M.A. Al-Ghouti, J. Ind. Eng. Chem. 28 (2015) 282.

[36] V. Masindi, M.W. Gitari, H. Tutu, M. DeBeer, J. Water Process. Eng. 15 (2017) 2.

[37] A. Soliemanzadeh, M. Fekri, Microp. Mesop. Mater. 239 (2017) 60 .

[38] B. Caglar, B. Afsin, E. Koksal, A. Tabak, E. Eren, Quím. Nova 36 (2013) 955.

[39] L. Zhirong, M.A. Uddin, S. Zhanxue, Spectrochim. Acta A 79 (2011) 1013.

[40] CONAMA, Nat. Environ. Council, 89, Resol. no 430 (2011).

(Rec. 13/06/2018, Rev. 08/08/2018, 27/09/2018, Ac. 27/10/2018) 